\title{
Assessment of the Developmental Toxicity of Epidermal Growth Factor using Embryonic Stem Cell Test
}

\author{
Fen Chen ${ }^{1}$, Fenfang $\mathrm{Cao}^{1}$, Zhijian $\mathrm{Su}^{2}$, Linyan $\mathrm{Li}^{1}$, Aibo Huang ${ }^{1}$ and Hua $\mathrm{Xu}^{1 *}$ \\ ${ }^{1}$ College of Pharmacy, ${ }^{2}$ Department of Biopharmaceutical Research and Development Centre, Jinan University, Guangzhou \\ 510632, Guangdong, People's Republic of China
}

*For correspondence: Email: huax-mail@163.com; Tel: 86-020-38375022

Received: 8 February 2014

Revised accepted: 22 April 2014

\begin{abstract}
Purpose: To determine whether epidermal growth factor (EGF) is involved in reproductive developmental toxicity, using the embryonic stem cell test (EST), as well as ascertain how EGF influences embryonic development.

Methods: To predict developmental toxicity on the basis of reducing cell viability and inhibition of differentiation of embryonic stem cells, EST was used to assess changes in different blastodermic genes and expression of proteins including ectodermal-specific genes Pax6, NF-H and glial fibrillary acidic protein (GFAP), mesodermal-specific genes BMP4, GATA4, and MyoD, and endodermal-specific genes, viz, a-fetoprotein, transthyretin (TTR), and albumin, as well as undifferentiated genes, Nanog and Oct4.

Results: The results indicate that EGF was weakly embryotoxic with $I C_{50} E S C$ (i.e., the concentration that reduced ESC viability by $50 \%$ ), IC $503 T 3$ (the concentration that reduced $3 T 3$ cell viability by $50 \%$ ), and $I D_{50} E S C$ (the concentration that inhibited differentiation of ESC by $50 \%$ ) of $6.773,10.531$, and $1.793 \mu \mathrm{g} / \mathrm{mL}$, respectively. The expression levels of tissue-specific genes of the three germ layers were mainly promoted by $0.01-1 \mu \mathrm{g} / \mathrm{mL}$ EGF. Distinctively, relatively high concentrations of EGF caused a discordant effect on the three germ layers. High concentrations of EGF promoted differentiation of the ectoderm and mesoderm, and either inhibited or had mostly no impact on the endoderm.

Conclusion: The imbalance of the three layer-specific genes and expression of proteins, as a result of EGF, might be responsible for its weak level of developmental toxicity. The sensitivity of TTR means that further investigation is required to determine whether it can be used as an embryotoxicity biomarker for growth factors.
\end{abstract}

Keywords: Embryonic stem cell test, Epidermal growth factor, Developmental toxicity, Germ layers, Blastodermic genes, Protein expression

Tropical Journal of Pharmaceutical Research is indexed by Science Citation Index (SciSearch), Scopus, International Pharmaceutical Abstract, Chemical Abstracts, Embase, Index Copernicus, EBSCO, African Index Medicus, JournalSeek, Journal Citation Reports/Science Edition, Directory of Open Access Journals (DOAJ), African Journal Online, Bioline International, Open-J-Gate and Pharmacy Abstracts

\section{INTRODUCTION}

Growth factors, including acidic fibroblast growth factor (aFGF), basic FGF (bFGF), nerve growth factor (NGF), epidermal growth factor (EGF), etc., are naturally occurring substances that are capable of stimulating cellular growth, proliferation and cellular differentiation, and also regulate a variety of cellular processes. In addition, they play an important role in the process of embryonic development [1]. For example, NGF may be of critical importance for ovarian follicles [2]. Insulin-like growth factor (IGF-I) participates in the regulation of fetal growth and development, and an abnormal level of IGF-I might be responsible for intrauterine growth retardation (IUGR) or large for date 
infants [3]. EGF promotes the proliferation, survival, and regeneration of multiple cell types, especially those of the ectoderm and mesoderm [4]. Previous research showed that abnormal expression of EGF and EGF receptor affected the normal development of the embryo, and that the serum and urine concentrations of EGF were significantly higher in infertile women than in a normal control group [5]. It is certain that EGF plays an important role in improving the rate of hatched blastocysts and reducing the apoptosis in vitro; when EGF concentration reached to 0.1 $\mu \mathrm{g} / \mathrm{mL}$, not only did the apoptosis and necrosis rate of embryonic cells significantly increase, but also embryonic development was inhibited [6]. Therefore, it is worth examining whether EGF has potentially toxic effects when used in a specific population, such as women in early pregnancy for a long time or at a large dose.

In the present study, we firstly evaluated the embryotoxic potential of EGF in vitro using a classic embryonic stem cell test (EST) protocol, and further investigated the effects of EGF on the developmental process. Embryotoxicity was determined by the three endpoints defined in the EST, which are $I_{50} E S C, I_{50} 3 T 3$, and ID $I_{50} E S C$. The embryotoxic mechanism of EGF was studied by detecting the expression of tissue-specific genes in three germ layers; ectodermal-specific genes NF-H, glial fibrillary acidic protein (GFAP), and Pax6, mesodermal-specific genes GATA4, MyoD, and BMP4, endodermal-specific genes $\alpha-$ fetoprotein (AFP), transthyretin (TTR) and albumin (ALB), as well as undifferentiated genes Nanog and Oct4. Combining this with the detection of tissue-specific proteins TTR, BMP4, and $\mathrm{NF}-\mathrm{H}$, we comprehensively investigated the way in which EGF affected embryonic development.

\section{EXPERIMENTAL}

\section{Cell culture}

Cells of the mouse embryonic stem (ES) cell line $\mathrm{OG}_{2}$ were purchased from Guangzhou Institute of Biomedicine and Health. Mouse embryonic fibroblasts (MEFs), which were extracted from 13.5 days post-coitum fetuses from Kun-ming mice, as the feeder layer, were inactivated with $10 \mu \mathrm{g} / \mathrm{mL}$ of mitomycin (Santa) for $3 \mathrm{~h}$. The ES cells were passaged on MEFs cultured on gelatin $(0.1 \%$, Sigma)-coated plates, maintained in KnockOut ${ }^{\text {TM }}$ Dulbecco's modified Eagle's medium (KnockOut DMEM; Gibco) at $37^{\circ} \mathrm{C}$ and 5 $\% \mathrm{CO}_{2}$. The medium was supplemented with $15 \%$ KnockOut $^{\mathrm{TM}}$ Serum Replacement (KSR; Gibco), $100 \mathrm{U} / \mathrm{mL}$ penicillin, and $100 \mathrm{U} / \mathrm{mL}$ streptomycin, $1 \%$ non-essential amino acids (Gibco), $0.1 \mathrm{mM} \beta$-mercaptoethanol (Sigma), and $1000 \mathrm{U} / \mathrm{mL}$ leukemia inhibitory factor (LIF; Millipore) to maintain their undifferentiated status. The medium was refreshed every day and ES cells were passaged every 3-4 days. The differentiation medium consisted of $15 \%$ fetal bovine serum (FBS; Gibco), instead of KSR, and an absence of LIF for complete development.

The Balb/c 3T3 cell line was purchased from the cell bank of Zhongshan Medical University, cultured in DMEM (Gibco) supplemented with $10 \%$ FBS (HyClone), $100 \mathrm{U} / \mathrm{mL}$ penicillin, and $100 \mathrm{U} / \mathrm{mL}$ streptomycin, and passaged every 2-3 days.

\section{Cytotoxicity measurement}

The cytotoxicity assay was performed as described [7], the cytotoxic effects of EGF on 3T3 and ES cells were determined by CCK8. On day 1,500 cells per $200 \mu \mathrm{L}$ medium were seeded in a 96-well plate and cultivated with a series of different concentrations of EGF for 10 days. The medium was renewed on days 3 and 5. On day 10, after incubating the cells with CCK8 solution (Sigma) for $1-3 \mathrm{~h}$ at $37^{\circ} \mathrm{C}$, absorbance was measured by a spectrophotometer at $450 \mathrm{~nm}$. The cytotoxicity of the test substance, expressed as the concentration that reduced the cell viability by $50 \%$ in comparison with control $\left(\mathrm{IC}_{50}\right)$, was determined from a concentration-response curve.

\section{ESC differentiation assay}

As previously described [8], 1000 cells in a droplet of $20 \mu \mathrm{L}$ medium were in a culture on the inner lid of a dish in a "hanging drop" to allow differentiation. During this period, the cells aggregated and became embryoid bodies (EBs), which are frequently used to facilitate differentiation toward cell types of all three germ layers [9]. After culturing for 3 days, the EBs were transferred to dishes containing EGF for another 2 days. On day 5, the EBs were seeded on $0.1 \%$ gelatin-coated 6-well plates and incubated for an additional 5 days for complete differentiation. The $I D_{50}$ of EGF, expressed as the concentration that suppressed the expression of $\beta-\mathrm{MHC}$ by $50 \%$ in comparison with control, was calculated from a concentration-response curve.

\section{Classification of the embryotoxic potential of EGF}

According to the guidelines of European Centre for the Validation of Alternative Methods 
Table 1: Primer sequences used for Q-PCR

\begin{tabular}{|c|c|c|}
\hline Genes & Sequences (5'-3') Forward & Sequences (3'-5') Reverse \\
\hline GAPDH & CCTTCCGTGTTCCTACCC & CCCAAGATGCCCTTCAGT \\
\hline$\beta-\mathrm{MHC}$ & GCCСTTTGACCTCAAGAAAG & CTTCACAGTCACCGTCTTGC \\
\hline Oct4 & GGTGGAGGAAGCCGACAAC & TTCGGGCACTTCAGAAACATG \\
\hline Nanog & CTCAAGTCCTGAGGCTGACA & TGAAACCTGTCCTTGAGTGC \\
\hline ALB & CAGCAATGGCAGGCAGATC & GGAACTTGCCAAGTACATGTGTGA \\
\hline AFP & CCTCAGCAGAGCTGATCGAC & AAAATGTCGGCCATTCCСTCA \\
\hline TTR & GTCCTCTGATGGTCAAAGTC & TCCAGTTCTACTCTGTACAC \\
\hline BMP4 & CTGCCGTCGCCATTCACTAT & TGGCATGGTTGGTTGAGTTG \\
\hline GATA4 & CTGGAGGCGAGATGG & GGTGGTGGTAGTCTGG \\
\hline MyoD & ACGGCTCTCTCTGCTCCTTTG & CGTGCTCCTCCGGTTTCA \\
\hline GFAP & TGCCACGCTTCTCCTTGTCT & GCTAGCAAAGCGGTCATTGAG \\
\hline $\mathrm{NF}-\mathrm{H}$ & GCAGGAGGAGTGCGGCTAC & CСAACСTCACTCGGAACCACT \\
\hline Pax6 & CCGCCCTCACCAACACGTACAGT & TTGCATGTGCGGAGGGGTGTAG \\
\hline
\end{tabular}

(ECVAM), combined with the three endpoints $I_{50} \mathrm{ESC}, \quad \mathrm{IC}_{50} 3 \mathrm{~T} 3$ and $\mathrm{ID}_{50} \mathrm{ESC}$, the test compound was classified into three categories as follows: non- embryotoxic (Class I), weakly embryotoxic (Class II) and strongly embryotoxic (Class III). Three endpoints obtained in each experiment were used to calculate Functions I, II, and III as shown below [10]:

I. $5.9157 \lg \left(\mathrm{IC}_{50} 3 \mathrm{~T} 3\right)+3.500 \lg \left(\mathrm{IC}_{50} \mathrm{ES}\right)-5.307$

$\left(\mathrm{IC}_{50} 3 \mathrm{~T} 3-\mathrm{ID}_{50} \mathrm{ES}\right) / \mathrm{IC} \mathrm{C}_{50} 3 \mathrm{~T} 3-15.72$

II. $3.6511 \mathrm{lg}\left(\mathrm{IC}_{50} 3 \mathrm{~T} 3\right)+2.3941 \mathrm{lg}\left(\mathrm{IC}_{50} \mathrm{ES}\right)-$ $2.033\left(\mathrm{IC}_{50} 3 \mathrm{~T} 3-\mathrm{ID}_{50} \mathrm{ES}\right) / \mathrm{IC} \mathrm{C}_{50} 3 \mathrm{~T} 3-6.85$

III.-0.125 Ig (IC ${ }_{50} 3$ T3) - $1.917 \mathrm{Ig}\left(\mathrm{IC}_{50} \mathrm{ES}\right)+1.500$

$\left(\mathrm{IC}_{50} 3 \mathrm{~T} 3-\mathrm{ID}_{50} \mathrm{ES}\right) / \mathrm{IC} \mathrm{C}_{50} 3 \mathrm{~T} 3-2.67$

The classification criteria were as follows: Class I: if I>II and I>III; Class II: if $\|>\mid$ and $\|>\| I \mid$; and Class III: if III>I and III>II.

\section{Real -time quantitative PCR (Q-PCR) analysis}

To verify the effect of EGF treatment on ES cells, the expression levels of ectoderm-specific genes (GFAP, NF-H and Pax6), mesoderm-specific genes (BMP4, GATA4 and MyoD), and endoderm-specific markers (AFP, TTR, and ALB) were analyzed by Q-PCR. Total RNA was extracted using an RNA extraction reagent kit (Sigma). The amount of RNA $(1 \mu \mathrm{g})$ required to reverse transcribe was quantified by PrimeScript $^{\circledR}$ 1st Strand cDNA Synthesis Kit (TAKARA), according to standard protocol, in a volume of $20 \mu \mathrm{L}$. Q-PCR was carried out using a SoAdvanced ${ }^{\mathrm{TM}} \quad$ SYBR $^{\circledR} \quad$ Green (Bio-rad), according to protocol is in a final volume of 20 $\mu \mathrm{L}$. The primer sequences are summarized in Table 1. The Q-PCR amplification protocol was as follows: $10 \mathrm{~min}$ at $95^{\circ} \mathrm{C}$ followed by 40 cycles at $95^{\circ} \mathrm{C}$ for $30 \mathrm{~s}$ and $60^{\circ} \mathrm{C}$ for $20 \mathrm{~s}$. GAPDH used as a reference gene to analyze the tissuespecific gene quantitatively.

\section{Western blot}

On day 10 after differentiation, the EBs were collected and extracted using protein lysate. The protein concentration was determined by a bicinchoninic acid protein assay kit (Thermo). After clearing by centrifugation at $12,000 \mathrm{~g}$ for 40 $\mathrm{min}$, the lysate was incubated with loading buffer and heat denatured for $10 \mathrm{~min}$. Proteins were separated by sodium dodecyl sulfate polyacrylamide gel electrophoresis and transferred to polyvinylidene difluoride membrane under a constant current, following which the membrane was blocked with $5 \%$ bovine serum albumin for 1 hour and incubated with the appropriate primary and secondary antibodies. Proteins were detected using enhanced chemiluminescence by ECL Western blot Kit (Bio-rad). GAPDH used as a reference gene to analyze tissue-specific protein quantitatively.

\section{Quantification and statistical analysis}

Q-PCR analysis and Western blots were quantified by densitometry using Bio-rad CFX Manager and ImageJ 1.44, respectively. All statistical analyses and graphs were prepared using GraphPad Prism 5 software. Data were analyzed by two-way analysis of variance coupled with a Bonferroni post hoc test or $t$ test, and $p<0.05$ was considered as statistically significant.

\section{RESULTS}

\section{Cytotoxic effects of EGF}

The cell viability assay was used to assess the cytotoxic effect of EGF on ES cells and Balbc3T3 fibroblasts, representing embryonic tissues and adult tissues, respectively. The results showed that, at a concentration range of 0.01 - 

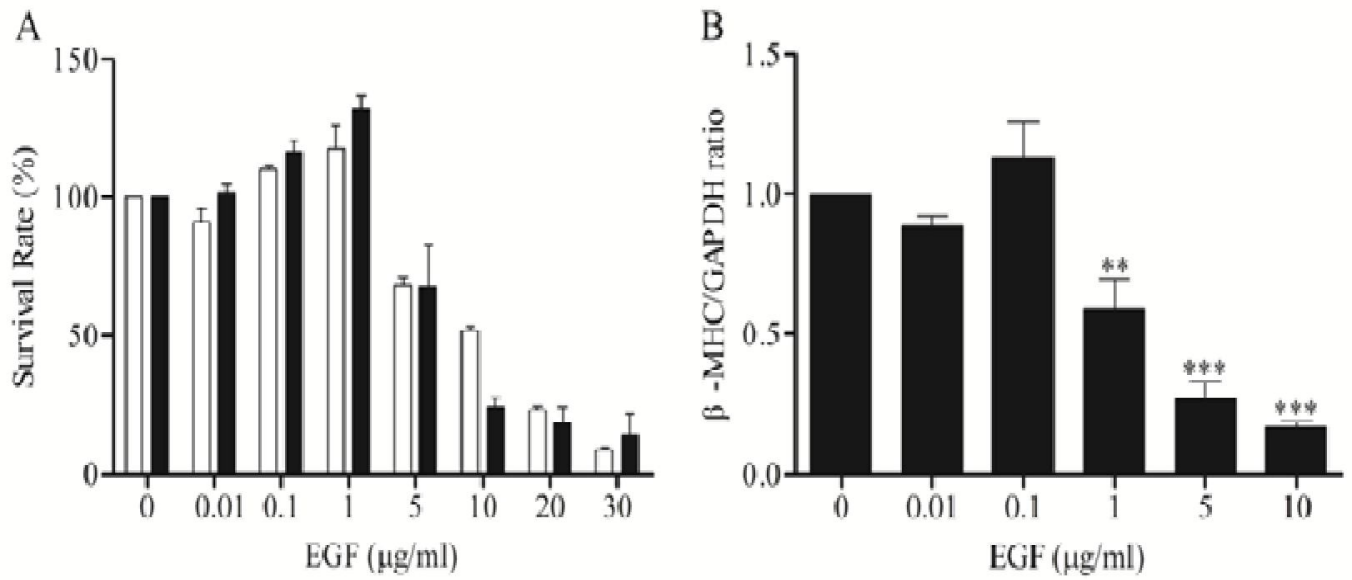

Fig 1: Effect of EGF on cytotoxicity and ES cell differentiation. (A) Cytotoxicity assay of EGF on ES cells and Balbc-3T3 fibroblasts (white column: Balbc-3T3; black column: ES cells). (B) $\beta-M H C$ expressions of EBs cultivated in the presence of EGF detected by Q-PCR. Data presented are the mean O.D. values ( \pm S.D.) of triplicate samples; ${ }^{*} p<0.05,{ }^{* *} p<0.01,{ }^{* * *} p<0.001$ versus control sample.

$30 \mu \mathrm{g} / \mathrm{mL}$ EGF induced or inhibited proliferation of the two cell lines at different levels (Fig 1A). EGF promoted ES cell proliferation at concentrations under $1 \mu \mathrm{g} / \mathrm{mL}$, while it inhibited cell survival when its concentration was higher than $1 \mu \mathrm{g} / \mathrm{mL}$. ES cells were more sensitive to cytotoxicity than Balbc-3T3 fibroblasts. IC $\mathrm{IC}_{50}$ concentrations, the inhibitory concentrations of $50 \%$ cell viability, were calculated at 6.773 $\mu \mathrm{g} / \mathrm{mL}$ and $10.531 \mu \mathrm{g} / \mathrm{mL}$ for ES cells and Balbc3T3 fibroblasts, respectively.

\section{Effect of EGF on ES cell differentiation}

To characterize the effects of EGF on ES cell differentiation, the sample that was extracted from the EBs was detected by Q-PCR in order to determine the expression levels of differentiation of specific gene $\beta-\mathrm{MHC}$ (Fig. 1B). The expression levels of $\beta-\mathrm{MHC}$ decreased except at the dose $0.1 \mu \mathrm{g} / \mathrm{mL}$ dose, showing that high doses of EGF inhibited the differentiation of ES cells. $I D_{50}$, the concentration that suppressed the expression of $\beta-\mathrm{MHC}$ by $50 \%$, was calculated from a concentration-response curve, and was $1.793 \mu \mathrm{g} / \mathrm{mL}$.

\section{Embryotoxicity of EGF}

According to the principle of ECVAM, combined with the three endpoints $\mathrm{IC}_{50} \mathrm{ESC}, \mathrm{IC}_{50} 3 \mathrm{~T} 3$ and $I_{50} E S C$, which when calculated were 6.773 $\mu \mathrm{g} / \mathrm{ml}, \quad 10.531 \mu \mathrm{g} / \mathrm{ml}$ and $1.793 \mu \mathrm{g} / \mathrm{ml}$, respectively, EGF was classified as weakly embryotoxic because of its II >I and II > III.

\section{Effects of EGF on the expression of three germ layer-specific markers}

To characterize the effects of EGF on the ES cell differentiation, the expression levels of tissuespecific genes and proteins were examined with EBs exposed to different concentrations of EGF on day 10 of differentiation. The results showed that the expression levels of undifferentiated genes Nanog and Oct4 increased in a dosedependent manner (Fig 2), which clearly showed that EGF impeded the differentiation of ES cells.

In the endoderm lineages, AFP and ALB, which are widely used as hepatic progenitor cell markers, increased with concentrations of up to 1 $\mu \mathrm{g} / \mathrm{mL}$ EGF, and then decreased. As shown in Fig 3, overall, mRNA expression of the endodermal marker, TTR, was declined in a dose-dependent manner. To assess the effect of EGF on differentiation of ES cells into the mesoderm lineage, we investigated mRNA expression of BMP4, cardiac-specific GATA4, and MyoD (Fig. 3). The expression level of the three genes was promoted by EGF at concentrations of $0.01-5 \mu \mathrm{g} / \mathrm{mL}$, but was reduced at a concentration of $10 \mu \mathrm{g} / \mathrm{ml}$. With regard to ectoderm lineages, GFAP, a representative astrocyte-specific marker, and NF-H and Pax6, which are later-stage neuron-specific markers, the expression showed the same tendency, increasing from $0.01-5 \mu \mathrm{g} / \mathrm{mL}$ (Fig 3 ).

The changes in the protein of EBs that were treated with $0.01-10 \mu \mathrm{g} / \mathrm{mL}$ EGF were detected via Western blot assay with three antibodies against TTR, BMP4, and NF-H, which are from the three germ layers, respectively (Fig 4). 

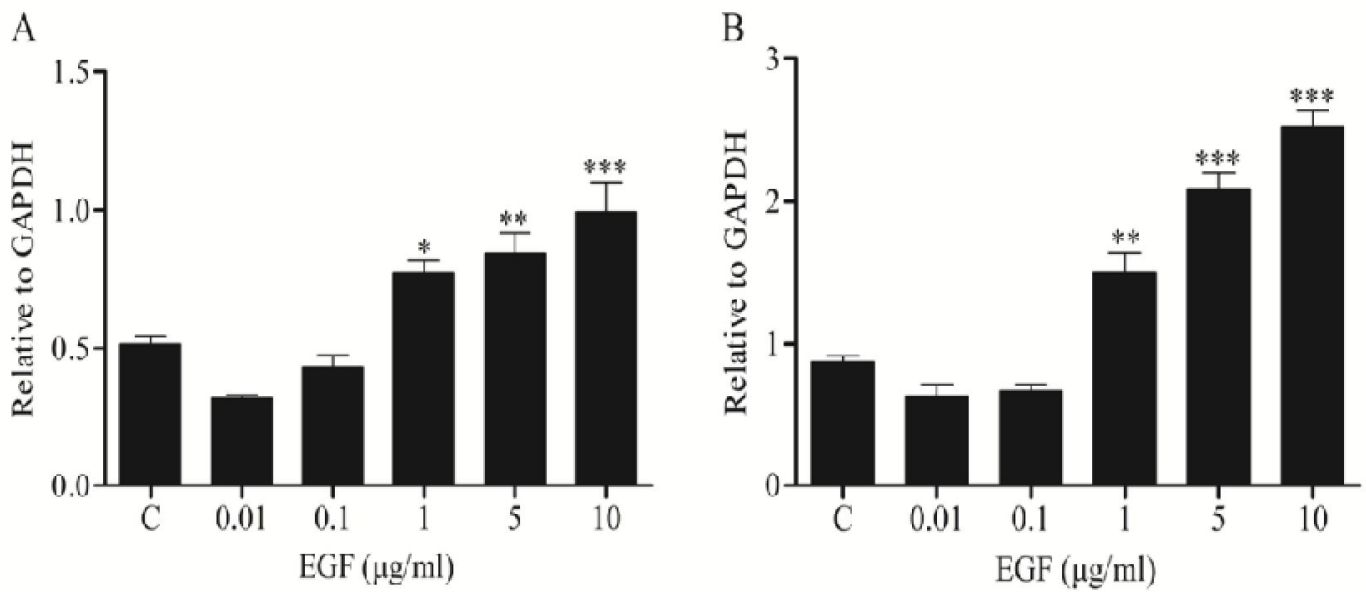

Fig 2: Effects of EGF on the expressions of undifferentiated genes Nanog and Oct4. (A-B) The expression levels of Nanog and Oct4 in EBs under corresponding concentrations of EGF. The data represented the mean of three independent experiments \pm standard deviation; $p<0.05$, ${ }^{* *} p<0.01$, ${ }^{* *} p<0.001$ versus the control sample.
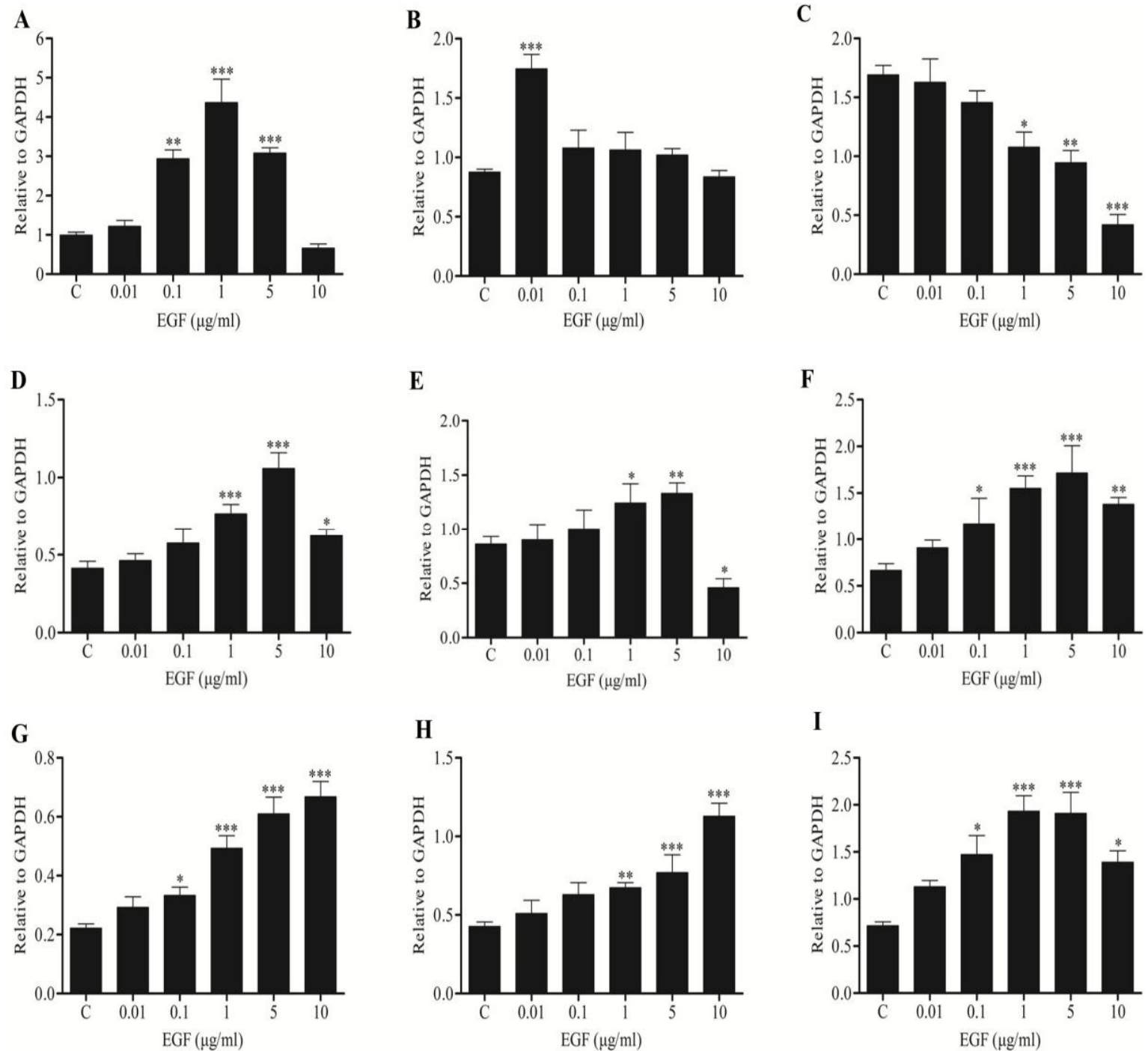

I

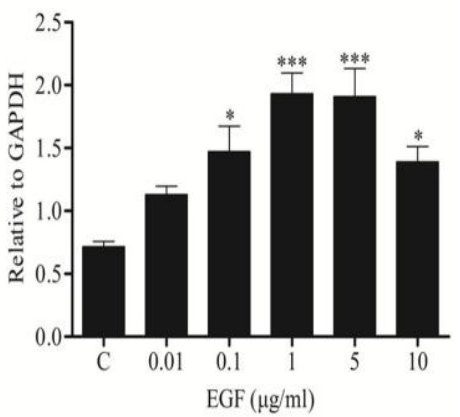

Fig 3: Effects of EGF on the expressions of three layers -specific markers. (A-C) The expression levels of AFP, $A L B$, and TTR in EBs under corresponding concentrations of EGF. (D-F) The expression levels of mesodermspecific genes BMP4, GATA4 and MyoD. (G-I) The expression levels of ectoderm-specific genes GFAP and Pax6, and NF-H. Data presented are the mean O.D. values ( \pm S.D.) of triplicate samples; ${ }^{*} p<0.05,{ }^{* *} p<0.01$, ${ }^{* * *} p<0.001$ versus the control sample 

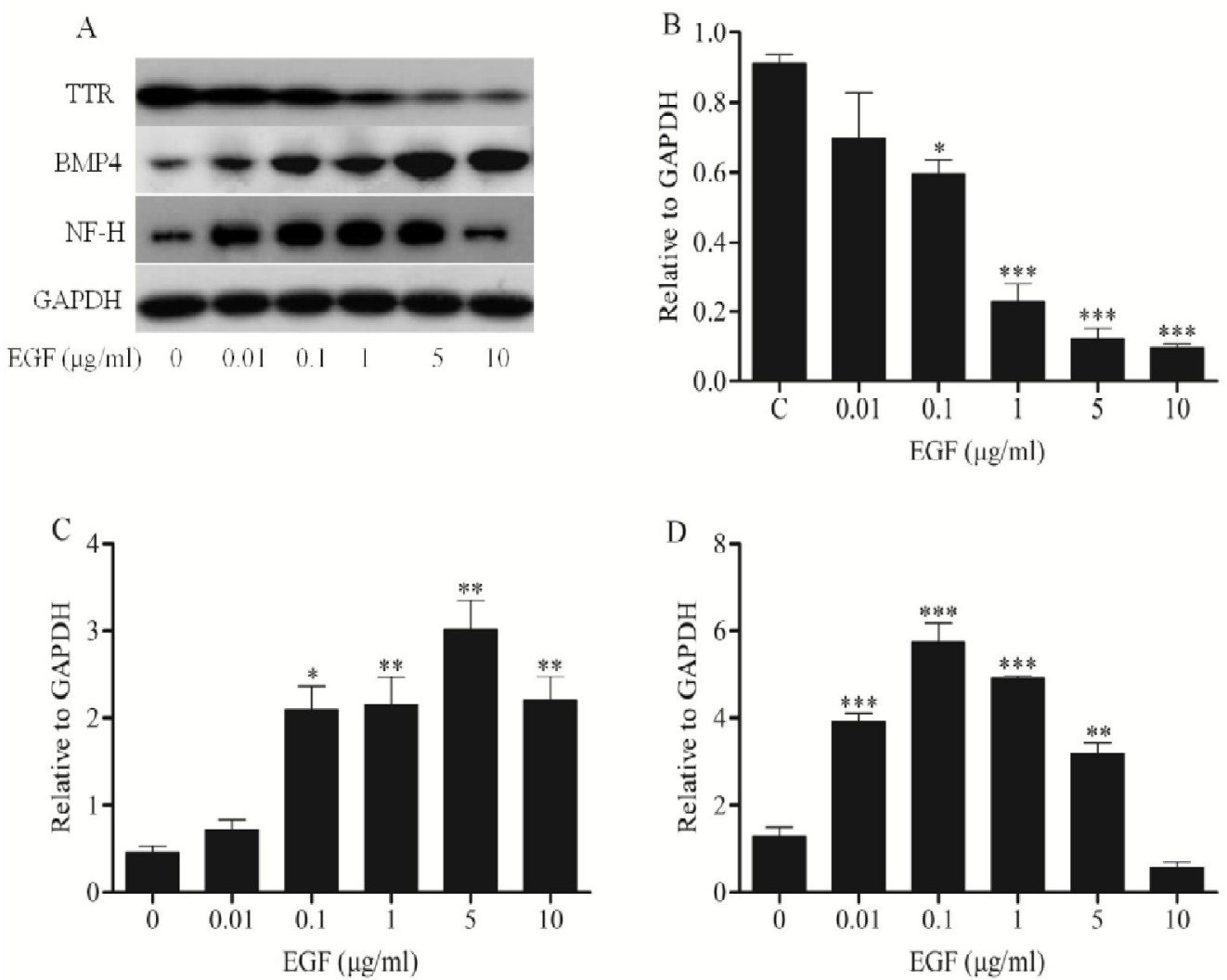

Fig 4: Effect of EGF on the expression of three layer-specific proteins. (A-D) The expression of TTR, BMP4, and NF-H in EBs under corresponding concentrations of EGF, were quantified with Western blot. Data are mean absorbance values $( \pm \mathrm{SD})$ of triplicate measurements; versus control.

Alterations in the three proteins coincided with changes in the gene levels

\section{DISCUSSION}

Developmental toxicity test systems have been established in vivo and in vitro. The in vivo tests are time-consuming and expensive, and are based on maternal or embryonic exposure of laboratory animals. Test models in vitro include those of whole embryo culture, ES cell micro mass cultivation, testicular cells, ovarian cells, and the EST [11]. With the advantage that only permanent cell lines are used, and consequently, no pregnant animals need be sacrificed to obtain embryonic cells, tissues or organs, EST validated by ECVAM was one of the most widely models to predict developmental toxicity [12]. ECVAM validation research has shown that prediction accuracy of EST for non- and weak embryotoxic compounds is $78 \%$, and is $100 \%$ for strong embryotoxicants [13].

EGF is a small molecular protein that was first identified in mouse submandibular gland. Research has shown that EGF is a strong mitogen that effectively promotes and adjusts the growth and proliferation of skin cells, induces cells to secrete hyaluronic acid and glycoprotein, and uniquely protects the skin and mucous membrane [14]. Due to its extensive biological activities, EGF has been widely used in the clinic, as well as in cosmetic materials used in cosmetic surgery. For example, EGF promotes fetal lung maturity, and has been used in clinical trials for the prevention and treatment of neonatal respiratory distress syndrome [15]. In addition, research has shown that EGF is an autocrine factor that regulates early placental growth, development, and hormone synthesis function, and also participates in the regulatory function of first trimester villi gonadotropin secretion. It has been reported that the absence of EGF, following removal of the mouse submandibular gland, obviously increases the rate of fetal rat abortion and results in IUGR in rat fetuses [5], whereas the addition of EGF, improves the rate of embryo implantation and promotes nuclear and cytoplasmic maturation promoted by facilitation of the increase of gonadotrophins [16]. In contrast, Buyalos indicated that a low concentration of EGF promoted embryonic development, while a high concentration of EGF inhibited the development of the embryo [17]. However, as an extraneous drug, it is worth investigating whether EGF results in any adverse 
impacts when used in the clinic.

In the present study, we first evaluated the embryotoxic potential of EGF using the classic EST protocol. The results revealed that EGF was a weak embryotoxicant, and so great attention should be paid to the fact that it may have embryotoxic potential when used in large doses, or long-term in low doses, especially in women in their first trimester of pregnancy.

Further, we investigated the way in which EGF made an impact on the expression of tissuespecific genes and proteins during the differentiation of mouse ES cells. The results showed that $0.01-10 \mu \mathrm{g} / \mathrm{mL}$ EGF had a suppressive differentiation effect, according to the expression levels of the undifferentiated genes Nanog and Oct4, which increased in a dose-dependent manner. As a whole, a relatively high concentration of EGF caused a discordant effect on the three germ layers. In particular, the expression of ectoderm-specific genes, including NF-H, GFAP, and Pax6, gradually increased at 0.01-5 $\mu \mathrm{g} / \mathrm{mL}$ EGF concentrations. The expression levels of $\mathrm{NF}-\mathrm{H}$, an intermediate filament protein unique for neurons [18], reached a maximum at $1 \mu \mathrm{g} / \mathrm{mL}$ EGF, while it diminished slightly when the concentration of EGF increased. GFAP, a marker of radial glial cells, and Pax6, which play an important role in the eyes, and central nervous system tissue and organ formation, as well as in the process of embryonic development, showed sustained increasing expression [19], which is in accordance with a previous finding that EGF stimulates cells that originate from the ectoderm and endoderm, such as corneal, epithelial, breast, nerve, glial, and adrenal medulla cells, etc., resulting in their proliferation [20].

In the mesoderm lineage, the overall expression of BMP4, GATA4, and MyoD showed a tendency to increase, and reached a maximum at $5 \mu \mathrm{g} / \mathrm{mL}$. It is worth mentioning that at the mRNA and protein expression level of BMP4, both showed a significant increase, which inferred that EGF is important in accelerating bone growth and tooth development. Compared to the above, the expression of the ectodermspecific gene AFP, which is widely used as a hepatic marker, showed a dose-dependent increase and decreased when the concentration of EGF exceeded $5 \mu \mathrm{g} / \mathrm{mL}$, which suggests that a low concentration of EGF promotes embryonic stem cell differentiation into hepatic cells, while, toxicity at a high concentration of EGF leada to inhibition. It has been reported that $20-45 \mathrm{ng} / \mathrm{mL}$ EGF can be used as an inducer to promote hepatic cell directional differentiation from stem cells [21]. Our results showed the promotion of hepatic differentiation effects of EGF on increased expression of the AFP gene. Most notably, TTR, a marker of late differentiation stage, showed an obvious linear decrease, which may infer that TTR is sensitive to EGF. Combined with the analysis of protein, the changes of TTR affected by EGF were also verified. With regard to preliminary toxicity studies on other growth factors, aFGF and bFGF, both displayed particularly sensitive expression of gene TTR, so it can be preliminarily determined that TTR is a sensitive gene to those growth factors, and can be considered as a toxicity marker gene in our next study.

\section{CONCLUSION}

Our results confirmed that EGF is a weak embryotoxicant. It could up-regulate the expressions of ectodermal- and mesodermalspecific genes, while it down-regulates or mostly has no impact on the expression of endodermspecific genes at the same EGF concentration. The imbalance of the three layer-specific genes and protein expressions caused by EGF showed that EGF promoted the differentiation of the ectoderm and mesoderm, and inhibited or had mostly no impact on the endoderm at high concentrations. The sensitivity of TTR means that further investigation is required to determine whether TTR changes could be used as embryotoxicity biomarkers for growth factors.

\section{ACKNOWLEDGMENT}

The study was supported by the National Natural Science Foundation of China (Grant no. 30973602) and the Natural Science Foundation of Guangdong Province, China (Grant no. S2011010001898), and for this, all the authors here express their deep thanks. Fen Chen and Fenfang Cao contributed equally to this work and should be considered co-first authors.

\section{REFERENCES}

1. zur Nieden NI, Kempka G, Ahr HJ. Molecular multiple endpoint embryonic stem cell test - a possible approach to test for the teratogenic potential of compounds. Toxicol Appl Pharmacol 2004; 194: 257-269.

2. Chaves RN, Alves AMCV, Lima LF, Matos HMT, Rodrigues APR, Figueiredo JR. Role of nerve growth factor (NGF) and its receptors in folliculogenesis. Zygote 2013; 21: 187-197.

3. Koklu E, Ozturk MA, Kurtoglu S, Akcakus M, Yikilmaz A, Gunes T. Aortic intima-media thickness, serum IGF-I, IGFBP-3, and leptin levels in intrauterine growth-restricted newborns of healthy mothers. Pediatr Res 2007; 62: 704-709. 
4. Gibbs S, Pinto ANS, Murli S, Huber M, Hohl D, Ponec M. Epidermal growth factor and keratinocyte growth factor differentially regulate epidermal migration, growth, and differentiation. Wound Repair Regen 2000; 8: 192-203.

5. Filla MS, Kaul KL. Relative expression of epidermal growth factor receptor in placental cytotrophoblasts and choriocarcinoma cell lines. Placenta 1997; 18: 1727.

6. Sotoyama H, Zheng YJ, Iwakura Y, Mizuno M, Aizawa M, Shcherbakova K, Wang R, Namba $H$, Nawa $H$. Pallidal Hyperdopaminergic Innervation Underlying D2 Receptor-Dependent Behavioral Deficits in the Schizophrenia Animal Model Established by EGF. PloS one 2011; 6: 467-472

7. zur Nieden NI, Ruf LJ, Kempka G, Hildebrand H, Ahr HJ. Molecular markers in embryonic stem cells. Toxicol in Vitro 2001; 15: 455-461.

8. Murabe M, Yamauchi J, Fujiwara $Y$, Miyamoto $Y$, Hiroyama M, Sanbe A, Tanoue A. Estimation of the embryotoxic effect of CBZ using an ES cell differentiation system. Biochem Biophys Res Commun 2007; 356: 739-744.

9. Doetschman TC, Eistetter H, Katz M, Schmidt W, Kemler $R$. The in vitro development of blastocyst-derived embryonic stem cell lines: formation of visceral yolk sac, blood islands and myocardium. J Embryol Exp Morphol 1985; 87: 27-45.

10. Festag $M$, Viertel $B$, Steinberg $P$, Sehner $C$. An in vitro embryotoxicity assay based on the disturbance of the differentiation of murine embryonic stem cells into endothelial cells. II. Testing of compounds. Toxicol in Vitro 2007: 21: 1631-1640.

11. Spielmann H. Predicting the risk of developmental toxicity from in vitro assays. Toxicol Appl Pharmacol 2005, 207: 375-380.

12. Scholz G, Genschow E, Pohl I, Bremer S, Paparella M, Raabe H, Southee J, Spielmann H. Prevalidation of the embryonic stem cell test (EST)-A new in vitro embryotoxicity test. Toxicol in Vitro 1999; 13: 675681.

13. Seiler AEM, Spielmann $H$. The validated embryonic stem cell test to predict embryotoxicity in vitro. Nat Protoc 2011; 6: 961-978.

14. Fatimah SS, Tan GC, Chua KH, Tan AE, Hayati AR. Effects of epidermal growth factor on the proliferation and cell cycle regulation of cultured human amnion epithelial cells. J Biosci Bioeng 2012; 114: 220-227.

15. Leslie CC, McCormick-Shannon K, Shannon JM, Garrick B, Damm D, Abraham JA, Mason RJ. Heparinbinding EGF-like growth factor is a mitogen for rat alveolar type II cells. Am J Respir Cell Mol Biol 1997; 16: 379-387.

16. De La Fuente R, O'Brien MJ, Eppig JJ. Epidermal growth factor enhances preimplantation developmental competence of maturing mouse oocytes. Hum Reprod 1999; 14: 3060-3068.

17. Buyalos RP, Cai X. Preimplantation embryo development enhanced by epidermal growth factor. J Assist Reprod Genet 1994; 11: 33-37.

18. Lalonde $R$, Strazielle $C$. Neurobehavioral characteristics of mice with modified intermediate filament genes. Rev Neurosci 2003; 14: 369-385.

19. Engelkamp $D$, Rashbass $P$, Seawright $A$, van Heyningen $V$. Role of Pax6 in development of the cerebellar system. Development 1999; 126: 3585-3596.

20. Huang C, Hu S, Chen B. Growth inhibition of epidermal growth factor-stimulated human glioblastoma cells by nicardipine in vitro. J Neurosurg Sci 2001; 45: 151-155.

21. Tan Y, Xiao EH, Xiao LZ, Yuan $Y H$, Ma C, Shang QL Bian DJ, Li YH, Chen Z, Chang Q. VEGF(165) expressing bone marrow mesenchymal stem cells differentiate into hepatocytes under HGF and EGF induction in vitro. Cytotechnology 2012; 64: 635647. 